\title{
Türkiye'deki Tip 2 Diyabet Hastalarında Serum Asimetrik Dimetilarjinin Düzeyleri ile Ateroskleroz Arasında Bir Korelasyon Var mıdır?
}

\author{
Osman Özdoğan', Bülent Çekiç²
}

ÖZET:

Türkiye'deki tip 2 diyabet hastalarında serum asimetrik dimetilarjinin düzeyleri ile ateroskleroz arasında bir korelasyon var mıdır?

Amaç: Ateroskleroz diabetes mellitus (DM) hastalarında çok yaygındır. Biz tip 2 DM hastalarında 'endojen nitrik oksit sentaz inhibitörü' olarak bilinen asimetrik dimetil arjinin (ADMA) ile ateroskleroz arasında bir ilişki olup olmadığını araştırdık.

Gereç ve Yöntemler: Tip 2 DM tanısı alan, yaş ortalaması $55.73 \pm 8.78$ yıl olan toplam 85 hasta (\%48.2 [n:41] erkek) çalışmaya dahil edildi. ADMA plazma seviyeleri, lipid profili, HbA1c gibi laboratuvar parametreleri değerlendirildi. Aterosklerozun bir göstergesi olan karotis intima-media kalınlığı (IMT) ölçüldü. Hastalar, yüksek ve düşük ADMA düzeyleri olarak iki gruba ayrıldı.

Bulgular: istatistiksel olarak serum ADMA düzeyleri ile total kolesterol $(r=0.045 ; p=0.684)$, trigliserid $(r=-0.067 ; p=0.544)$, LDL kolesterol $(r=0.142 ; p=0.194)$ ve HDL kolesterol $(r=0.085 ; p=0.085)$ arasında anlamlı ilişki saptanmadı. ADMA düzeyi ile HbA1c arasında ( $r=0.376 ; p=0.001)$ ve serum ADMA düzeyi ve karotis-intima media kalınlığı arasında $(r=0.321 ; p=0.003)$ istatistiksel olarak anlamlı bir ilişki saptandı.

Sonuç: Serum ADMA düzeyi karotis IMT ile ilişkilidir. Tip 2 DM hastalarında ADMA düzeylerinin değerlendirilmesi koroner arter hastalığı gibi aterosklerotik hastalıkları öngörmede yararlı olabilir.

Anahtar kelimeler: Asimetrik dimetil arjinin, ateroskleroz, tip 2 diyabet

\section{ABSTRACT:}

Is there a correlation between plasma levels of asymmetric dimethylarginine (ADMA) levels and atherosclerosis in type 2 diabetes patients in Turkey?

objective: Atherosclerosis is very common in patients with diabetes mellitus (DM). We aimed to investigate the relationship between asymmetric dimethylarginine (ADMA) which is known as 'an endogenous inhibitor of nitric oxide synthase' and atherosclerosis among patients with a diagnosis of type 2 DM.

Material and Methods: A total of 85 patients with a diagnosis of type 2 DM (48.2\% [n: 41] male) with a mean age of $55.73 \pm 8.78$ years were enrolled in this trial. Plasma levels of ADMA, and laboratory parameters such as lipid profile and $\mathrm{HbA1C}$ were evaluated. Carotid intima-media thickness (IMT), a marker of atherosclerosis was measured. The patients were classified into two groups as cases with high and low ADMA levels.

Results: No statistically significant correlation was found between serum ADMA levels and total cholesterol $(r=0.045 ; p=0.684)$, triglyceride $(r=-0.067 ; p=0.544)$, LDL cholesterol $(r=0.142 ; p=0.194)$ and HDL cholesterol $(r=0.085 ; p=0.085)$. A statistically significant correlation was determined between serum ADMA level and $\mathrm{HbA1c}(r=0.376 ; p=0.001)$ and between serum ADMA level and carotid-intima media thickness ( $r=0.321 ; p=0.003$ ).

Conclusions: Serum ADMA level is correlated with carotid IMT. Evaluation of ADMA levels in type 2 DM patients may be helpful in predicting atherosclerotic diseases such as coronary artery disease. Keywords: Asymmetric dimethylarginine, atherosclerosis, type 2 diabetes mellitus

Ş.E.E.A.H. Tıp Bülteni 2017;51(1):63-70 1'stanbul Eğitim ve Araştırma Hastanesi, Dahiliye Kliniği, İstanbul - Türkiye 2istanbul Eğitim ve Araştırma Hastanesi, Radyoloji Kliniği, İstanbul - Türkiye

Yazışma Adresi / Address reprint requests to: Osman Özdoğan,

İstanbul Eğitim ve Araştırma Hastanesi, Dahiliye Kliniği, İstanbul - Türkiye

E-posta / E-mail: osmanozdogan2000@gmail.com

Geliş tarihi / Date of receipt: 29 Ağustos 2016 / August 29, 2016

Kabul tarihi / Date of acceptance: 5 Aralık 2016 / December 5, 2016 


\section{GíRiş}

Koroner arter hastalığına (KAH) eşdeğer olarak dünya çapında kabul gören diabetes mellitus (DM) prevalansı giderek artmaktadır (1). Diyabetik olgularda prematüre ve subklinik kardiyovasküler hastalığın yaygınlık oranları, hastaların kan şekeri düzeylerine bakılmaksızın $\geq \% 70$ olarak bildirilmektedir (2).

Endotel disfonksiyonu farklı çalışmalarda önemli bir kardiyovasküler risk faktörü olarak gösterildi (3). Endotel disfonksiyonu, trombositlerin adezyon ve agregasyonunu, vasküler düz kas hücre proliferasyonunu ve düşük yoğunluklu lipoprotein (LDL) oksidasyonunu, monositlerin ve lökositlerin endotele adezyonunu önleyen nitrik oksidin (NO) biyoyararlanımında bir azalma olarak tanımlanmaktadır (4). Asimetrik dimetilarginin (ADMA) temelde endotelyal nitrik oksit sentetaz (eNOS) için yarışmalı bir inhibitördür. ADMA, NO üretim oranını düzenler. Plazma ADMA konsantrasyonu diabetes mellitus, periferik arter hastalığı, hipertansiyon, kardiyovasküler hastalık gibi endotel disfonksiyonu ile ilişkili hastalıkların seyri boyunca arttığı gösterilmiştir (5-9).

Karotis arter intima media kalınlığı (IMK) yetişkinlerde aterosklerozun bir göstergesidir. $\mathrm{KAH}$ şiddeti ile korelasyon gösterir ve esas olarak erken ateroskleroza bağlı kardiyovasküler hastalığın önemli bir göstergesidir (10-12).

DM'li hastalarda, KAH genellikle diyabetik olmayan vakalarla karşılaştırıldığında subklinik seyir gösterir (13) ve yüksek mortalite insidansı ile birlikte görülür (14). Bu nedenle, erken teşhis çok önemlidir. Çeşitli çalışmalarda $(12,13)$ serum ADMA düzeyi ile karotis IMK arasında anlamlı korelasyon bildirilmesine ragmen, bazı çalışmalarda $(15,16)$ plazma ADMA düzeyleri ile koroner endotel fonksiyonları, kardiyovasküler hastalık arasında korelasyon bulunmamıştır. Daha önceki çalışmalarda ADMA ile diabetes mellitus arasındaki ilişki tartışmalı olup net değildir. Bu veriler yetersizdir ve sonuçları doğrulamak için farklı ülkelerde ve hasta gruplarında yapılan yeni çalışmalar gerekmektedir. Ülkemizde bu yönde bir çalışma yoktur. Bu çalışmanın amacı, tip 2 DM'li hastalarda serum
ADMA düzeyleri ile karotis IMK, lipit parametreleri ve HbA1c arasındaki ilişkiyi araştırmaktır.

\section{GEREÇ VE YÖNTEM}

Hastaların kaydı: Bu çalışmaya Diyabet Polikliniği'nde daha önce tanı konmuş ve halen tedavi gören toplam 85 tip 2 DM (41 erkek, 44 kadın) hasta dahil edilmiştir. Tansiyon> 140/90 mm $\mathrm{Hg}$ olan veya antihipertansif ilaçlarla tedavi edilen hastalar hipertansiyon pozitif olarak değerlendirildi. İskemik kalp hastalığı, lipid düşürücü ajan kullanım öyküsü, trigliserid düzeyi> $400 \mathrm{mg} / \mathrm{dl}$, ailevi dislipidemi öyküsü, nefropati öyküsü (artmış üre, kreatinin seviyeleri, mikroalbüminüri), tiroid fonksiyon bozukluğu ve alkol tüketim öyküsü olan hastalar çalışmaya alınmadı. Hastaların demografik verileri ve antropometrik ölçümleri kaydedildi. Her hasta için boy ve kilo baz alınarak vücut kitle indeksi (VKi) [ağırlık (kg) / yükseklik $\left(\mathrm{m}^{2}\right)$ ] hesaplandı.

Biyokimyasal laboratuvar testleri ve ADMA seviyelerinin ölçülmesi: En az 12 saat açlık sonrası sabah kan örnekleri alındı. Rutin testler Klinik Biyokimya Laboratuvarı ve Klinik Mikrobiyoloji Laboratuvarı'nda yapıldı. Açlık kan şekeri, total kolesterol, trigliserid, HDL-kolesterol ve hemoglobin A1c seviyeleri Aeroset 2.0 analizöründe (Abbott Laboratories) çalışıldı. LDL-kolesterol seviyeleri, Friedewald formülüyle (toplam kolestrol - [HDL kolesterol + (trigliserid / 5)] hesaplandı.

Plazma ADMA seviyelerinin ölçülmesi; Kan 1 saat içinde santrifüjlenmek üzere (2.500 gr 10 dakika) EDTA içeren $6 \mathrm{~mL}$ vakum tüplerine (Becton Dickonson, lot no: 8169826) alındı; Elde edilen plazma örnekleri $-80^{\circ} \mathrm{C}^{\prime}$ de tutuldu. ELISA metodunda (Immundiagnostik AG, Almanya), peroksidaz enzimi için substrat olarak tetrametilbenzidin (TMB) kullanıldı, sonra poliklonal ADMA-antiserum ile karıştırıldı. Plazma ADMA seviyeleri, $450 \mathrm{~nm}$ dalga boyunda elde edilen absorbans değerleri ile ters orantılı olarak tespit edildi $(17,18)$.

Karotis IMK'nın ultrasonografik belirlenmesi: Karotis IMK ölçümlerinde standardizasyon sağla- 
mak için, hastanın verilerine sahip olmayan aynı hekim tarafından LOGIQ-7 GE Ultrason cihazı ile Radyoloji Bölümü'nde değerlendirme yapıldı. Hasta muayene sırasında sırtüstü pozisyonda tutuldu. Baş kısmı muayene edilecek tarafın zıt yönüne bakacak şekilde boyun hafif ekstansiyonda tutuldu. Gri skala muayene $10 \mathrm{MHz}$ problarla yapıldı. Transvers projeksiyonda gri skala muayenesi başlatıldı. İşlem, bilateral supraklaviküler girintiden başlayarak mandibular açıya kadar kapsayacak şekilde servikal arterin tüm trasesi boyunca gerçekleştirildi. Mevcut araştırmada, her iki karotis arterinde de ölçümler yapıldı. IMK, lümen intima kenarından medya ve adventisya marjına kadar olan alan olarak tanımlandı. Ölçümler, ultrasonun B modunda ekstrakranial vasküler yapıların plak içermeyen alanlarında gerçekleştirildi. Bilateral karotis arterlerde IMK en kalın bölgede değerlendirildi. Ölçümlerin ortalama değerleri hesaplandı ve kaydedildi.

Etik: Araştırmaya başlanmadan önce her bir hastadan bilgilendirilmiş onam alındı. Bu çalışmanın etik onayı, hastanemizin yerel etik komitesi tarafından verildi.

\section{İstatistiksel Analiz}

İstatistiksel değerlendirmeler için SPSS (statistical package for social sciences, for Windows, release 12.0.0 standard version) yazılımı kullanılmıştır. Ölçeğin değişkenliği ortalama \pm standart sapma (ortalama \pm SS) olarak ifade edildi. $p<0.05$ değeri istatistiksel olarak anlamlı kabul edildi. Student's test, Mann Whitney u testi ve ki-kare testi değişkenlerin karşılaştırılmasında kullanıldı. Pearson yöntemi korelasyon analizinde kullanılmıştır. $p<0.05$ anlamlı kabul edildi.

\section{BULGULAR}

Kayıtlı olan hastaların \%48.2'si $(n=41)$ erkek, \%51.8'i (n=44) kadın idi. Hipertansif hastalar tüm olguların \%50.6'sını ( $n=43)$ oluşturdu. Tüm vakaların \%68.2'si $(n=58)$ oral antidiyabetik ilaç kullanırken, \%31.8'i ( $n=27)$ insülin tedavisi görüyordu. 49 hasta $(\% 57.7)$ sigara kullanmakta idi. Hastaların yaş
Tablo-1: Tüm hastaların genel özellikleri

\begin{tabular}{|c|c|c|}
\hline ADMA $(\mu \mathrm{mol} / \mathrm{L})$ & & $0.6288 \pm 0.2000$ \\
\hline \multirow{2}{*}{ Cinsiyet $(n, \%)$} & Kadın & $41(48.2)$ \\
\hline & Erkek & $44(51.8)$ \\
\hline \multicolumn{2}{|l|}{ Yaş, yıl } & $55.73 \pm 8.78$ \\
\hline \multicolumn{2}{|l|}{ Vki $\left(\mathrm{kg} / \mathrm{m}^{2}\right)$} & $29.09 \pm 4.02$ \\
\hline \multicolumn{2}{|l|}{ DM süresi, yıl } & $6.52 \pm 4.68$ \\
\hline \multirow[t]{2}{*}{ Tedavi $(n, \%)$} & OAD & $58(68.2)$ \\
\hline & İnsulin & $27(31.8)$ \\
\hline \multirow[t]{2}{*}{ HT $(n, \%)$} & Hayır & $41(49.4)$ \\
\hline & Evet & $43(50.6)$ \\
\hline \multirow[t]{2}{*}{ Sigara $(n, \%)$} & Hayır & $36(42.3)$ \\
\hline & Evet & $49(57.7)$ \\
\hline \multicolumn{2}{|l|}{ HbA1c } & $7.670 \pm 1.395$ \\
\hline \multicolumn{2}{|l|}{ Total kolesterol (mg/dL) } & $208.60 \pm 30.45$ \\
\hline \multicolumn{2}{|l|}{ TG $(\mathrm{mg} / \mathrm{dL})$} & $187.46 \pm 79.14$ \\
\hline \multicolumn{2}{|l|}{ LDL (mg/dL) } & $131.48 \pm 26.02$ \\
\hline \multicolumn{2}{|l|}{ HDL (mg/dL) } & $40.16 \pm 7.46$ \\
\hline \multicolumn{2}{|l|}{ TSH (mU/L) } & $1.98 \pm 1.09$ \\
\hline \multicolumn{2}{|l|}{ IMT (mm) } & $0.934 \pm 0.200$ \\
\hline \multicolumn{3}{|c|}{$\begin{array}{l}\text { ADMA: Asimetrik dimetil arjinin, VKi: Vücut kitle indeksi, } \\
\text { HT: Hipertansiyon, OAD: Oral antidiyabetik DM: Diyabetes Mellitus, FT4: Serbest TC } \\
\text { HDA1c: Hemoglobin A1c, HDL: Yüksek yoğunluklu lipoprotein } \\
\text { iMK: Intima-media kalınlığı, LDL: Düsük yoğunluklu lipoprotein } \\
\text { TG: Trigliserid, TSH: Tiroid stimüle hormon }\end{array}$} \\
\hline
\end{tabular}

ortalaması $55.73 \pm 8.78$ yıl olup, diğer parametreler Tablo-1'de gösterildi.

Serum ADMA düzeyinin laboratuar ve klinik verilerle korelasyonu istatistiksel olarak değerlendirildi. Serum ADMA düzeyleri ile total kolesterol $(r=0.045 ; p=0.684)$, trigliserit $(r=-0.067 ; p=0.544)$, LDL kolesterol $(r=0.142 ; p=0.194)$, HDL kolestrol $(r=0.085 ; p=0.085), T S H(r=-0.046 ; p=0.674)$, serbest T4 $(r=-0.19 ; p=0.864)$, kreatinin $(r=0.052$; $\mathrm{p}=0.639)$ ve üre $(\mathrm{r}=0.046 ; \mathrm{p}=0.674)$ düzeyleri arasında istatiksel olarak anlamlı bir korelasyon yoktu. Serum ADMA düzeyi ile $\mathrm{HbA} 1 \mathrm{c}$ düzeyleri arasında istatistiksel olarak anlamlı korelasyon bulundu $(r=0.376 ; p<0.001)$ (Grafik-1). Serum ADMA düzeyi ile karotis intima-media kalınlığı arasında istatistiksel olarak anlamlı korelasyon saptandı ( $r=0.321$; $\mathrm{p}=0.003)$ (Grafik-2).

Kit ekinde $(n=70)$ tanımlanan çalışmanın sonuçlarına göre, sağlıklı bireylerde ADMA'nın plazma seviyeleri için beklenen değerler 0.26-064 $\mu \mathrm{mol} / \mathrm{L}$ olarak belirtilmekte idi. HPLC (High Performance Liquid Chromatography) ve LC-MS (Liquid Chromatography - Mass Spectrophotometry) ile yapılan çalışmalarda normal ADMA aralığı 0.225-0.485 $\mu \mathrm{mol} / \mathrm{L}$ olarak ifade edilmişti $(14,15)$. Biz hastalarımızı ADMA düzeyleri $0.6 \mu \mathrm{mol} / \mathrm{L}^{\prime} n$ in altında ve 


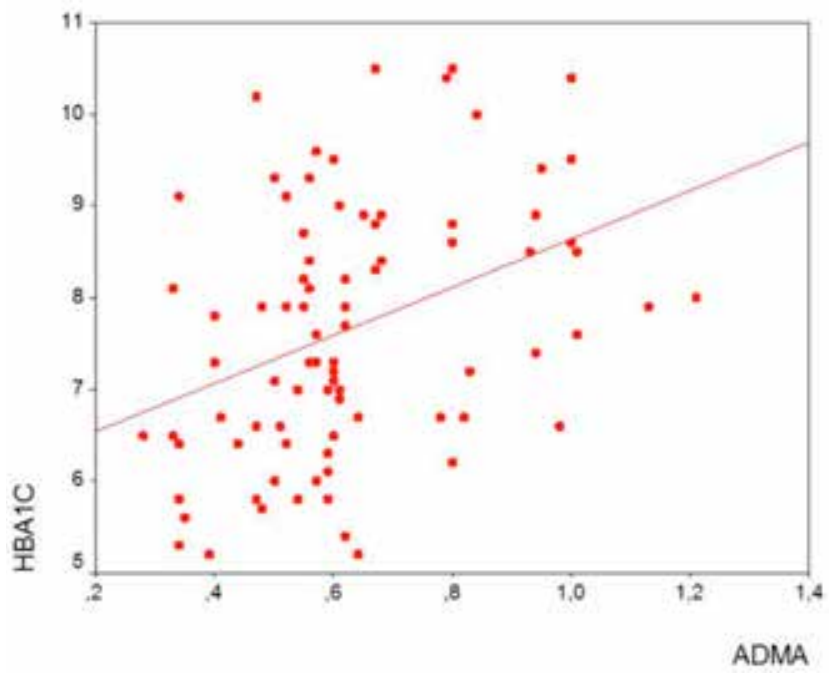

Grafik-1: ADMA düzeyi ile Hblc arasındaki korelasyon Regresyon analizinde serum ADMA düzeyi ile HbA1c arasındaki doğrusal pozitif korelasyon

$0.6 \mu \mathrm{mol} / L^{\prime}$ nin üzerinde olan iki grupa ayırdık ve bu iki grupta da değerlendirme yaptık. Bu iki grubun genel demografik özelliklerinin karşılaştırılması Tablo-2'de gösterilmektedir. ADMA düzeyi $0.6 \mu \mathrm{mol} / \mathrm{L}^{\prime}$ de düşük olan grup ile yüksek olan grup arasında $V K i$, yaş, diyabet süresi, cinsiyet dağılımı, tedavi şekli, sigara içimi, hipertansiyon açısından anlamlı fark bulunmadı ( $p>0.05$ ).

ADMA düzeyleri $0.6 \mu \mathrm{mol} / \mathrm{L}^{\prime}$ nin altındaki ve üzerinde olan olguların laboratuvar ve radyolojik

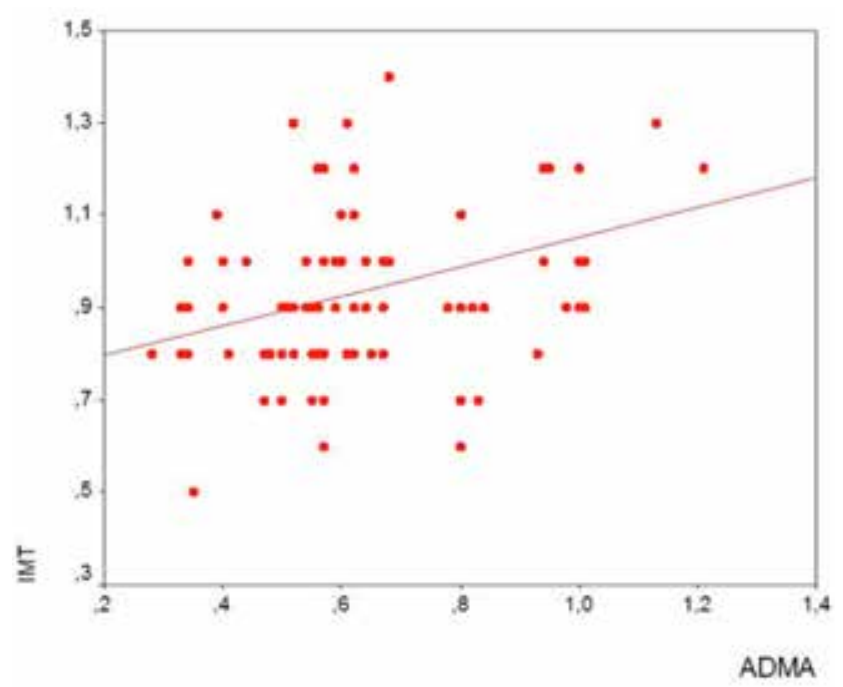

Grafik-2: ADMA düzeyi ile karotid intima-media kalınlığı arasındaki korelasyon

Serum ADMA düzeyi ile karotis intima-media kalınlığı arasındaki pozitif istatistiksel korelasyon regresyon analizinde gözlendi

verilerinin karşılaştırılması Tablo-3'de gösterilmektedir. Total kolesterol, TG, LDL, TSH, FT4, üre ve kreatinin düzeyleri açısından iki grup arasında anlamlı fark bulunmamıştır ( $p>0.05)$. ADMA değerleri $0.6 \mu \mathrm{mol} / \mathrm{L}^{\prime}$ nın üzerinde olan olguların HbA1c seviyeleri, IMK değerleri ADMA $0.6 \mu \mathrm{mol} / \mathrm{L}^{\prime} \mathrm{n} ı \mathrm{n}$ altındaki hastalara göre anlamlı derecede yüksekti $(p<0.01)$.

Tablo-2: Serum ADMA düzeyleri $0.6 \mu \mathrm{mol} / \mathrm{L}$ 'nin altında ve üzerinde olan olguların genel demografik özelliklerinin karşılaştırılması

\begin{tabular}{|c|c|c|c|c|}
\hline & & \multicolumn{2}{|c|}{ ADMA düzeyi } & \multirow[b]{2}{*}{ p değeri } \\
\hline & & $\begin{array}{c}<0.6 \mu \mathrm{mol} / \mathrm{L} \\
(\mathrm{n}=43)\end{array}$ & $\begin{array}{c}\geq 0.6 \mu \mathrm{mol} / \mathrm{L} \\
(n=42)\end{array}$ & \\
\hline \multirow[t]{2}{*}{ Cinsiyet $(n, \%)$} & Kadın & $23(53.5)$ & $21(50)$ & 0.748 \\
\hline & Erkek & $20(46.5)$ & $21(50)$ & \\
\hline \multirow[t]{2}{*}{ Tedavi $(n, \%)$} & OAD & $32(74.4)$ & $26(61.9)$ & 0.215 \\
\hline & İnsulin & $11(25.6)$ & $16(38.1)$ & \\
\hline \multirow[t]{2}{*}{ Sigara $(n, \%)$} & Hayır & 27 (62.8) & $22(52.4)$ & 0.180 \\
\hline & Evet & $16(37.2)$ & $20(47.6)$ & \\
\hline \multirow[t]{2}{*}{ HT $(n, \%)$} & Hayır & $21(48.8)$ & $22(52.4)$ & 0.744 \\
\hline & Evet & $22(51.2)$ & $20(47.6)$ & \\
\hline Kilo (kg) & & $81.44 \pm 12.48$ & $78.76 \pm 11.61$ & 0.309 \\
\hline Boy $(\mathrm{cm})$ & & $163.11 \pm 26.39$ & $164.93 \pm 9.31$ & 0.675 \\
\hline Vki $\left(k g / m^{2}\right)$ & & $29.09 \pm 4.02$ & $28.97 \pm 3.91$ & 0.887 \\
\hline Yaş, yıl & & $55.74 \pm 8.55$ & $55.71 \pm 9.50$ & 0.988 \\
\hline DM yaşı, yıl & & $5.86 \pm 4.51$ & $7.19 \pm 4.81$ & 0.192 \\
\hline
\end{tabular}

ADMA: Asimetrik dimetil arjinin, VKi: Vücut kütle indeksi, HT: Hipertansiyon, OAD: Oral antidiyabetik 
Tablo-3: ADMA düzeyleri $0.6 \mu \mathrm{mol} / \mathrm{L}$ 'nin (ortalama $\pm S D$ ) altındaki ve üzerinde olan olguların laboratuvar ve radyolojik verilerinin karşılaştırılması

\begin{tabular}{|c|c|c|c|}
\hline & \multicolumn{2}{|c|}{ ADMA düzeyi } & \multirow[b]{2}{*}{ p değeri } \\
\hline & $\begin{array}{c}<0.6 \mu \mathrm{mol} / \mathrm{L} \\
(\mathrm{n}=43)\end{array}$ & $\begin{array}{c}\geq 0.6 \mu \mathrm{mol} / \mathrm{L} \\
(\mathrm{n}=42)\end{array}$ & \\
\hline Total kolesterol (mg/dl) & $207.74 \pm 26.73$ & $209.50 \pm 34.14$ & 0.792 \\
\hline TG $(\mathrm{mg} / \mathrm{dl})$ & $188.67 \pm 68.02$ & $186.21 \pm 89.94$ & 0.887 \\
\hline LDL $(\mathrm{mg} / \mathrm{dl})$ & $128.19 \pm 23.05$ & $134.86 \pm 28.63$ & 0.240 \\
\hline HDL (mg/dl) & $41.63 \pm 7.59$ & $38.67 \pm 7.10$ & 0.067 \\
\hline TSH (mU/L) & $2.14 \pm 1.24$ & $1.83 \pm 0.90$ & 0.204 \\
\hline FT4 (ng/dL) & $1.28 \pm 0.36$ & $1.25 \pm 0.16$ & 0.597 \\
\hline Üre (mg/dl) & $29.95 \pm 9.90$ & $30.24 \pm 4.95$ & 0.866 \\
\hline Kreatini (mg/dl) & $0.87 \pm 0.15$ & $0.82 \pm 0.18$ & 0.103 \\
\hline HbA1c (\%) & $7.24 \pm 1.33$ & $8.11 \pm 1.34$ & 0.003 \\
\hline iMK (mm) & $0.87 \pm 0.15$ & $1.00 \pm 0.22$ & 0.003 \\
\hline
\end{tabular}

FT4: Serbest T4, HbA1c: Hemoglobin A1c, HDL: Yüksek yoğunluklu lipoprotein, iMK: Intima-media kalınlığı, LDL: Düşük yoğunluklu lipoprotein, HDL: Yüksek yoğunluklu lipoprotein, TG: Trigliserid, TSH: Tiroid stimüle hormonu

Plazma ADMA düzeyleri ( $\mu \mathrm{mol} / \mathrm{L})$ erkeklerde $(n=41) \quad 0.6456 \pm 0.2137$, kadınlarda $(n=44)$ $0.6131 \pm 0.1877$ olarak belirlendi ve cinsiyetler arasında istatistiksel olarak anlamlı fark yoktu $(p=0.460)$. Sigara içen ve sigara içmeyen hastalar arasında $(p=0.920)$ ve hipertansif ve normotansif hastalar arasında istatistiksel olarak anlamlı fark bulunamadı $(p=0.830)$.

\section{TARTIŞMA}

Bu çalışmada, serum ADMA'nın tip 2 diyabetik hastalarda ateroskleroz belirteçleri ile ilişkili olup olmadığını araştırdık. Çalışmamız tip 2 DM hastalarında ADMA düzeylerinin karotis IMK ve HbA1c ile pozitif korelasyon gösterdiğini ortaya koymuştur. Serum ADMA konsantrasyonları VKi, lipit parametreleri, cinsiyet, diyabet süresi ve yaş ile veya diğer ateroskleroz risk faktörleri ile korelasyon göstermedi.

Ülkemizde ve dünyadaki en yaygın hastalıklardan biri olan tip 2 diabetes mellitusun önemi her geçen gün artmaktadır. Kardiyovasküler hastalık $(\mathrm{KVH})$, tip 2 diyabetli hastalarda morbidite ve mortalitenin önde gelen nedenidir (19). Bu konuyla ilgili çalışmaların temel amacı, hastalığın gelişmesinden önce $\mathrm{KVH}$ riskini belirlemek ve diyabetli hastalarda $\mathrm{KVH}^{\prime}$ nın gerçekleşmesini önlemektir. Bu amaçla, çalışmalar öncelikle arginin'den nitrik oksidin sentezinden sorumlu olan nitrik oksit sen- tetaz eziminin inhibitörü ADMA' ya odaklanmıştır. Nitrik oksid normal endotel fonksiyonunun sürdürülmesinde vazgeçilmez bir maddedir $(20,21)$.

Yaptığımız çalışmada tip 2 DM'li hastalarda ADMA ve karotis IMK arasında anlamlı korelasyon tespit ettik. Daha önceki çalışmalarda, karotis iMK'nin KAH şiddeti ile korelasyon gösterdiği ve erken aterosklerozun önemli bir göstergesi olduğu gösterildi $(10,11)$. Miyazaki ve ark. (22), karotis IMK ve ADMA arasında anlamlı bir korelasyon bulunduğunu tespit etti. Kocak ve ark. (23) peritoneal diyaliz hastalarında karotis IMK ve ADMA düzeyleri arasında kuvvetli bir korelasyon saptamıştır. Ari Hasan ve ark. (24) 104 hasta üzerinde bir araştırma yaptı ve ADMA seviyelerinin diyabet, hipertansiyon, LDL ve total kolestrolden bağımsız olarak KVH açısından prediktif bir değere sahip olduğunu bildirdi. Prospektif ve büyük ölçekli bir çalışma olan AtheroGene çalışmasında yüksek ADMA düzeyi, konvansiyonel risk faktörlerinden bağımsız olarak kardiyovasküler riskin güçlü bir göstergesi olduğu belirtildi (25). Bir başka çalışmada, KVH gelişme riski ADMA düzeylerinde her $1 \mu \mathrm{mol} / \mathrm{l}$ artışda yaklaşık $2.35 \mathrm{~kat}$ arttı $\breve{g}_{\mathrm{I}}$ bildirilmiştir (26). Ayrı bir araştırmada, yüksek ADMA düzeyleri, fatal ve non-fatal miyokard enfarktüsü ve akut koroner sendromdan sonra ortaya çıkan tüm nedenlere bağlı kardiyovasküler mortalite için güçlü ve bağımsız bir gösterge olarak belirlendi (27). Öte yandan, bir başka çalışma- 
da elde edilen sonuçlar, ADMA düzeyinin yüksek olduğu vakaların ileride beş yıl içinde diyabet mellitus kardiyovasküler komplikasyonlara neden olabileceğini gösterdi (28). DM hastalarında yapıIan son çalışmaların sonuçları yüksek ADMA düzeylerinin kardiyovasküler hastalıklarda prediktif bir değeri olabileceğini düşündürmektedir (2931). Çalışmamıza ve literatür verilerine dayanarak, serum ADMA düzeyinin tip 2 DM hastalarında $\mathrm{KAH}$ için prediktif bir değere sahip olduğu sonucuna varabiliriz.

Son 2-3 ay boyunca ortalama kan glikoz düzeylerini belirten $\mathrm{HbA1c}$, son zamanlarda diyabetin yeni bir teşhis kriteri olarak kabul edildi (32). Mevcut araştırmamızda, HbA1c ve serum ADMA seviyeleri arasında pozitif bir korelasyon bulduk. Eliana ve ark. (33) prediabetik kadınlar üzerinde bir araştırma yaptı ve ADMA ve HbA1c arasında bir korelasyon belirledi. Hsu ve ark. (34) plazma ADMA düzeyi ile HbA1c seviyesi arasında anlamlı bir korelasyon saptamadı. Öte yandan Marcovecchio ve ark. (35), tip 1 DM hastalarında HbA1c ve ADMA arasında ters bir ilişki bildirmiştir. Yasuda ve ark. (36) hastaneye yatırılan tip 2 DM hastalarında, yoğun glukoz kontrolü, standart tedaviyle karşılaştırıldığında ADMA düzeylerini daha etkin bir şekilde düşürdügünü göstermiştir. Sonuç olarak, ADMA ve HbA1c arasındaki korelasyon karotis IMK ve ADMA arasındaki korelasyon kadar belirgin değildir.

Çalışmamızda, sigara içimi ile ADMA arasında bir korelasyon bulamadık. Bu konu ile ilgili çelişkili literatür bilgileri mevcuttur. Zhang WZ ve ark. (37), sigara içenlerde ADMA düzeylerinin yükseldiğini gösterirken ve 563 yaşlı erkek hastada yapılan başka bir çalışmada zıt sonuçların bildirildiğini bildirdiler (38). Vaka kontrol çalışmasında Maas ve ark. (39) yüksek ADMA düzeylerinin sigara içmeyenler arasında koroner arter hastalığının öngörülmesinde anlamlı olduğunu, sigara içenlerde ise önemsiz olduğu bildirilmiştir. Bu bulgunun, sigara dumanında ADMA metabolize eden bir bileşenle ilişkili olduğu ileri sürülmüştür.

Mevcut araştırmamızda ADMA düzeyleri ile HT, VKi, lipid paneli, cinsiyet, diyabet süresi ve yaş değişkenleri arasında anlamlı bir ilişki bula- madık. Xia ve ark. (40), sistemik endotel disfonksiyonu ve ateroskleroz ile ADMA arasındaki korelasyon üzerine, 2012 yılında 72 tip 2 diyabetli hasta üzerinde bir araştırma yaptı ve diyabetik yaş, HbA1c, lipid düzeyleri, hipertansiyon ve kreatinin klirensi ile anlamlı korelasyon bulunmamakla birlikte, plazma ADMA düzeyi ile carotid iMK arasında güçlü bir korelasyon tespit etti. Meinitzer ve ark. (20) ADMA ile HT, VKi ve LDL Kolesterolü arasında istatistiksel olarak anlamlı bir korelasyon bulamazken ADMA ile trigliserid ve HDL kolesterol düzeyleri arasında anlamlı korelasyon saptadı.. Markus Juonala ve ark. (41), 2096 genç Finlandiyalı hasta üzerinde bir araştırma yaptı ve daha düşük ADMA değerleri olan grupla karşılaştırıldığında yüksek ADMA düzeyleri olan grupta $\mathrm{HDL}$, trigliserid ve izole sistolik basıncın daha düşük seviyede buldu. LDL ve toplam kolesterol arasında anlamlı bir korelasyon saptamadı. Altınova ve ark. (42) tarafından tip 1 DM hastalarında yürütülen bir araştırmada, yüksek ADMA düzeyleri VKi, açlık kan şekeri, LDL kolestrolü ile pozitif korelasyon saptanırken HDL kolesterolü ile ADMA arasında ise negatif korelasyon bildirildi. Onat ve ark.nın çalışmasında (43), plazma ADMA konsantrasyonları açısından kadın ve erkek hasta grupları arasında anlamlı bir fark gözlenmemiştir. Benzer şekilde, plazma ADMA düzeyleri ile toplam yaş ortalaması arasındaki fark istatistiksel olarak anlamlı bulunmamıştır. Aynı araştırmanın sonuçları, plazma ADMA düzeyleri ile HDL kolesterolü, LDL kolesterolü, toplam kolesterol arasında pozitif bir korelasyon olduğunu ortaya koydu. Sigara içenler ve içmeyenler arasında anlamlı bir korelasyon gözlenmemiştir. ADMA'nın HT, BKi, lipit parametreleri, cinsiyet, diyabet süresi ve yaş ile korelasyonu konusundaki çelişkili veriler elde edilmiştir.

Tip 2 DM hastalarında yaptığımız çalışmada, karotis IMK ve HbA1c ile ADMA düzeyleri arasında pozitif korelasyon bulundu. VKi, lipid parametreleri, cinsiyet, diyabet süresi ve yaş ile anlamlı bir korelasyon saptanmadı. ADMA düzeylerinde yapılan önceki çalışmaların değerlendirilmesiyle, tip 2 DM'li hastalarda ADMA düzeyi ile ateroskleroz arasında bir ilişki olduğunu söyleyebiliriz. 


\section{Çalışma sınırlamaları}

Çalışmada, ateroskleroz için karotis IMK sadece değerlendirildi. Ateroskleroz için bir başka parametrede değerlendirmeye katılabilirdi. Çalışma sonrasın-

\section{KAYNAKLAR}

1. American Diabetes Association. Standards of medical care in diabetes-2015 abridged for primary care providers. Clin Diabetes 2015; 33: 97-111. [CrossRef]

2. Barzilay II, Spiekerman CF, Kuller LH, Burke GL, Bittner $V$, Gottdiener JS, et al. Prevalence of clinical and isolated subclinical cardiovascular disease in older adults with glucose disorders: the Cardiovascular Health Study. Diabetes Care 2001; 24: 1233-9. [CrossRef]

3. Brunner H, Cockcroft JR, Deanfield J, Donald A, Ferrannini E, Halcox J, et al. Endothelial function and dysfunction. Part II: Association with cardiovascular risk factors and diseases. A statement by the Working Group on Endothelins and Endothelial Factors of the European Society of Hypertension. J Hypertens 2005; 23: 233-46. [CrossRef]

4. Kerkeni M, Addad F, Chauffert M, Myara A, Ben Farhat $M$, Miled A, et al. Hyperhomocysteinemia, endothelial nitric oxide synthase polymorphism, and risk of coronary artery disease. Clin Chem 2006; 52: 53-8. [CrossRef]

5. Anderson JL, Carlquist JF, Roberts WL, Horne BD, May HT, Schwarz EL, et al. Asymmetric dimethylarginine, cortisol/ cortisone ratio, and C-peptide: markers for diabetes and cardiovascular risk? Am Heart J 2007; 153: 67-73. [CrossRef]

6. Wilson AM, Shin DS, Weatherby C, Harada RK, Ng MK, Nair $N$, et al. Asymmetric dimethylarginine correlates with measures of disease severity, major adverse cardiovascular events and allcause mortality in patients with peripheral arterial disease. Vasc Med 2010; 15: 267-74. [CrossRef]

7. Achan V, Broadhead M, Malaki M, Whitley G, Leiper J, MacAllister $R$, et al. Asymmetric dimethylarginine causes hypertension and cardiac dysfunction in humans and is actively metabolized by dimethylarginine dimethylaminohydrolase. Arterioscler Thromb Vasc Biol 2003; 23: 1455-9. [CrossRef]

8. Schulze F, Lenzen H, Hanefeld C, Bartling A, Osterziel KJ, Goudeva $L$, et al. Asymmetric dimethylarginine is an independent risk factor for CHD: results from the multicenter Coronary Artery Risk Determination investigating the Influence of ADMA Concentration (CARDIAC) study. Am Heart J 2006; 152: 493-8. [CrossRef]

9. Bal UA, Yıldırır A, Aydinalp A, Kaynar G, Kanyilmaz S, Murat $K$, et al. Could plasma asymmetric dimethylarginine level be a novel predictor beyond the classic predictors of stent restenosis? Anadolu Kardiyol Derg 2014; 14: 491-7. [CrossRef]

10. O'Leary DH, Polak JF, Kronmal RA, Manolio TA, Burke GL, Wolfson SK Jr. Carotid-artery intima and media thickness as a risk factor for myocardial infarction and stroke in older adults. Cardiovascular Health Study Collaborative Research Group. N Engl J Med 1999; 340: 14-22. [CrossRef]

11. Lorenz MW, Markus HS, Bots ML, Rosvall M, Sitzer M. Prediction of clinical cardiovascular events with carotid intima-media thickness: a systematic review and meta-analysis. Circulation 2007; 115: 459-67. [CrossRef] da hastaların izlenmesi sürdürülebilinirdi. Hasta sayısı daha fazla olabilir ve kontrol grubu alınabilirdi.

\section{Yazar veya makale ile ilgili çıkar çatışması:} Çıkar çatışması belirtilmedi.
12. Bernard $S$, Serusclat $A$, Targe $F$, Charriere $S$, Roth $O$, Beaune $J$, et al. Incremental predictive value of carotid ultrasonography in the assessment of coronary risk in a cohort of asymptomatic type 2 diabetic subjects. Diabetes Care 2005; 28: 1158-62. [CrossRef]

13. Deluca AJ, Saulle LN, Aronow WS, Ravipati G, Weiss MB. Prevalence of silent myocardial ischemia in persons with diabetes mellitus or impaired glucose tolerance and association of hemoglobin A1C with prevalence of silent myocardial ischemia. Am J Cardiol 2005; 95: 1472-4. [CrossRef]

14. Jacoby $R M$, Nesto $R W$. Acute myocardial infarction in the diabetic patient: pathophysiology, clinical course and prognosis. J Am Coll Cardiol 1992; 20: 736-44. [CrossRef]

15. Maas R, Quitzau K, Schwedhelm E, Spieker L, Rafflenbeul W, Steenpass $A$, et al. Asymmetrical dimethylarginine (ADMA) and coronary endothelial function in patients with coronary artery disease and mild hypercholesterolemia. Atherosclerosis 2007; 191: 211-9. [CrossRef]

16. Böger RH, Sullivan LM, Schwedhelm E, Wang TJ, Maas $R$, Benjamin EJ, et al. Plasma asymmetric dimethylarginine (ADMA) and incidence of cardiovascular disease and death in the community. Circulation 2009; 199: 1592-600. [CrossRef]

17. Marra M, Bonfigli AR, Testa R, Testa I, Gambini A, Coppa G. High-performance liquid chromatographic assay of asymmetric dimethylarginine, symmetric dimethylarginine, and arginine in human plasma by derivatization with naphthalene-2,3dicarboxaldehyde. Anal Biochem 2003; 318: 13-7. [CrossRef]

18. Martens-Lobenhoffer J, Krug O, Bode-Böger SM. Determination of arginine and asymmetric dimethylarginine (ADMA) in human plasma by liquid chromatography/mass spectrometry with the isotope dilution technique. J Mass Spectrom 2004; 39: 1287-94. [CrossRef]

19. Johnstone MT, Nesto R. Diabetes mellitus and heart disease. In: Pickup JC, Williams G, editors. Joslin's Diabetes Mellitus. 14th ed. Philadelphia, PA, USA: Lippincott Williams and Wilkins; 2005. pp. 975-98.

20. Meinitzer A, Seelhorst U, Wellnitz B, Halwachs-Baumann $G$, Boehm BO, Winkelmann BR, et al. Asymmetrical dimethylarginine independently predicts total and cardiovascular mortality in individuals with angiographic coronary artery disease (the Ludwigshafen Risk and Cardiovascular Health study). Clin Chem 2007; 53: 273-83. [CrossRef]

21. Stühlinger MC, Conci E, Haubner BJ, Stocker EM, Schwaighofer J, Cooke JP, et al. Asymmetric dimethyl L-arginine (ADMA) is a critical regulator of myocardial reperfusion injury. Cardiovasc Res 2007; 75: 417-25. [CrossRef]

22. Miyazaki H, Matsuoka H, Cooke JP, Usui M, Ueda S, Okuda S, et al. Endogenous nitric oxide synthase inhibitor: a novel marker of atherosclerosis. J Cardiol 1999; 33: 105-11. [CrossRef]

23. Kocak H, Gumuslu S, Ermis C, Mahsereci E, Sahin E, Gocmen $A Y$, et al. Oxidative stress and asymmetric dimethylarginine is independently associated with carotid intima media thickness in peritoneal dialysis patients. Am J Nephrol 2008; 28: 91-6. [CrossRef] 
24. Ari H, Ari S, Erdoğan E, Tiryakioğlu O, Ustündağ Y, Huysal K, et al. A novel predictor of restenosis and adverse cardiac events: asymmetric dimethylarginine. Heart Vessels 2010; 25: 19-26. [CrossRef]

25. Schnabel R, Blankenberg $S$, Lubos E, Lackner KJ, Rupprecht HJ, Espinola-Klein $C$, et al. Asymmetric dimethylarginine and the risk of cardiovascular events and death in patients with coronary artery disease: results from the AtheroGene Study. Circ Res 2005; 97: 53-9. [CrossRef]

26. Schulze $F$, Lenzen $H$, Hanefeld $C$, Bartling A, Osterziel KJ, Goudeva $L$, et al. Asymmetric dimethylarginine is an independent risk factor for coronary heart disease: results from the multicenter Coronary Artery Risk Determination investigating the Influence of ADMA Concentration (CARDIAC) study. Am Heart J 2006; 152: 493-8. [CrossRef]

27. Cavusoglu E, Ruwende C, Chopra V, Yanamadala S, Eng C, Pinsky DJ, et al. Relationship of baseline plasma ADMA levels to cardiovascular outcomes at 2 years in men with acute coronary syndrome referred for coronary angiography. Coron Artery Dis 2009; 20: 112-7. [CrossRef]

28. Konya H, Miuchi M, Satani K, Matsutani S, Yano Y, Tsunoda T, et al. Asymmetric dimethylarginine, a biomarker of cardiovascular complications in diabetes mellitus. World J Exp Med 2015; 5: 110-9. [CrossRef]

29. Krzyzanowska K, Mittermayer F, Wolzt M, Schernthaner G. Asymmetric dimethylarginine predicts cardiovascular events in patients with type 2 diabetes. Diabetes Care 2007; 30: 1834-9. [CrossRef]

30. Lajer M, Tarnow L, Jorsal A, Teerlink $T$, Parving HH, Rossing $P$. Plasma concentration of asymmetric dimethylarginine (ADMA) predicts cardiovascular morbidity and mortality in type 1 diabetic patients with diabetic nephropathy. Diabetes Care 2008; 31: 747-52. [CrossRef]

31. Celik M, Cerrah S, Arabul M, Akalin A. Relation of asymmetric dimethylarginine levels to macrovascular disease and inflammation markers in type 2 diabetic patients. J Diabetes Res 2014; 2014: 139215. [CrossRef]

32. Nathan DM, Balkau B, Bonora E, Borch-Johnsen K, Buse JB, Colagiuri $S$, et al. International Expert Committee, International Expert Committee report on the role of the A1C assay in the diagnosis of diabetes. Diabetes Care 2009; 32: 1327-34. [CrossRef]

33. Eliana F, Suwondo P, Makmun LH, Harbuwono DS. AADMA as a marker of endothelial dysfunction in prediabetic women. Acta Medica Indones 2011; 43: 92-8.
34. Hsu CP, Hsu PF, Chung MY, Lin SJ, Lu TM. Asymmetric dimethylarginine and long-term adverse cardiovascular events in patients with type 2 diabetes: relation with the glycemic control Cardiovasc Diabetol 2014; 13: 156. [CrossRef]

35. Marcovecchio ML, Widmer B, Turner C, Dunger DB, Dalton $R N$. Asymmetric dimethylarginine in young people with Type 1 diabetes: a paradoxical association with $\mathrm{HbA}(1 \mathrm{c})$. Diabet Med 2011; 28: 685-91. [CrossRef]

36. Yasuda S, Miyazaki S, Kanda M, Goto Y, Suzuki M, Harano Y, et al. Intensive treatment of risk factors in patients with type-2 diabetes mellitus is associated with improvement of endothelial function coupled with a reduction in the levels of plasma asymmetric dimethylarginine and endogenous inhibitor of nitric oxide synthase. Eur Heart J 2006; 27: 1159-65. [CrossRef]

37. Zhang WZ, Venardos K, Chin-Dusting J, Kaye DM. Adverse effects of cigarette smoke on NO bioavailability: role of arginine metabolism and oxidative stress. Hypertension 2006; 48: 27885. [CrossRef]

38. Eid HM, Arnesen H, Hjerkinn EM, Lyberg T, Seljeflot I. Relationship between obesity, smoking, and the endogenous nitric oxide synthase inhibitor, asymmetric dimethylarginine. Metabolism 2004; 53: 1574-9. [CrossRef]

39. Maas R, Schulze F, Baumert J, Löwel H, Hamraz K, Schwedhelm $E$, et al. Asymmetric dimethylarginine, smoking, and risk of coronary heart disease in apparently healthy men: prospective analysis from the population-based Monitoring of Trends and Determinants in Cardiovascular Disease/Kooperative Gesundheitsforschung in der Region Augsburg study and experimental data. Clin Chem 2007; 53: 693-701. [CrossRef]

40. Xia W, Shao $Y$, Wang $Y$, Wang X, Chi Y. Asymmetric dimethylarginine and carotid atherosclerosis in Type 2 diabetes mellitus. J Endocrinol Invest 2012; 35: 824-7. [CrossRef]

41. Juonala $M$, Viikari JS, Alfthan $G$, Marniemi J, Kähönen $M$, Taittonen $L$, et al. Brachial artery flow-mediated dilation and asymmetrical dimethylarginine in the cardiovascular risk in young Finns study. Circulation 2007; 116: 1367-73. [CrossRef]

42. Altinova AE, Arslan $M$, Sepici-Dincel A, Akturk $M$, Altan N, Toruner FB. Uncomplicated type 1 diabetes is associated with increased asymmetric dimethylarginine concentrations J Clin Endocrinol Metab 2007; 92: 1881-5. [CrossRef]

43. Onat A, Köroğlu B, Can G, Karagöz A, Yüksel M, Aydın M. Apparently "low" serum asymmetric dimethylarginine is associated with fasting glucose and tends toward association with type-2 diabetes. Anatol J Cardiol 2014; 14: 26-33. 